\title{
TINJAUAN PRINSIP-PRINSIP EKONOMI ISLAM DALAM PRAKTIK MEMASARKAN IKAN ASIN \\ (Studi Kasus Di Desa Lambur Luar Kecamatan Muara Sabak Timur)
}

\author{
Wandi; M. Arif Musthofa; Ratnah Ningsih \\ STIE Syari'ah Al-Mujaddid Jambi \\ e-mail: huseinwandi220@gmail.com; 7ariefherio@gmail.com; \\ ningsihratna@gmail.com
}

\begin{abstract}
This research is motivated by the writer's anxiety regarding the Review of Islamic Economic Principles in Marketing of Salted Fish (Case Study in Lambur Luar Village, Muara Sabak Timur District). The purpose of this research is how are the factors that hinder the marketing of Salted Fish in Lambur Luar Village. What are the obstacles marketing Salted Fish in Lambur Luar Village. In general, the result is from the analysts, the practice of buying and selling salted fish in Lambur Luar village where a seller sells salted fish which is still wet and has damaged fish is also not in accordance with the initial words. There are those who consider it a normal thing, but there are also those who feel disadvantaged. Those who think it is normal are justified because their goal is for the buyer to eat and be delicious or satisfied. The view of Islamic law on the practice of buying and selling salted fish in Lambur Luar village has two legal conclusions. Namely: first, the law is permissible because the buyer and seller have a willing heart, while the second is haram because in the heart, there is no willingness from the buyer of the salted fish
\end{abstract}

Keywords: practice;marketing; salted fish

\section{Pendahuluan}

Kegiatan ekonomi merupakan suatu aktivitas atau usaha yang dilakukan manusia, untuk mewujudkan kemakmuran dalam perekonomian. Kegiatan ekonomi bukan hanya sekedar untuk mendesain menjadi manusia ekonomi kreatif, melainkan juga makhluk sosial. Oleh karena itu, kegiatan ekonomi seharusnya di arahkan untuk memenuhi kebutuhan individual sekaligus kebutuhan rakyat secara keseluruhan. ${ }^{1}$ Manusia sebagai makhluk sosial dalam kehidupannya membutuhkan interaksi di mana mereka dapat mengambil dan memberikan manfaat. Salah satu praktik yang merupakan hasil interaksi sesama manusia adalah terjadinya jual beli yang dengannya mereka mampu mendapatkan kebutuhan yang mereka inginkan.

Islam menghalalkan usaha perdagangan, perniagaan, atau jual beli. Namun tentu saja untuk orang yang menjalankan usaha perdagangan secara Islam dituntut menggunakan tata cara khusus, salah satu contohnya yaitu seorang muslim dalam kegiatannya dalam jual beli agar mendapatkan berkah dan rida Allah di dunia dan akhirat. ${ }^{2}$

Jual beli dalam terminologi fikih disebut dengan al-bay' yang berarti menjual, mengganti, dan menukar sesuatu dengan sesuatu dengan yang lain. Menurut al-Nawawi dalam al-Мајти', mengatakan jual beli adalah pertukaran harta dengan harta untuk

\footnotetext{
${ }^{1}$ M. Nur Rianto Al Arif, Pengantar Ekonomi Syariah Teori dan Praktik (Bandung: CV Pustaka Setia, 2015$), 30$.

${ }^{2}$ Nasrun Haroen, Fiqh Muamalah Kontemporer (Jakarta: Rajawali Pers, 2016), 26.
} 
kepemilikan. Menukar barang dengan barang atau barang dengan uang dengan jalan melepaskan hak milik atas dasar saling merelakan. ${ }^{3}$

Bisnis dalam dunia perdagangan merupakan salah satu hal yang sangat penting dalam kehidupan manusia. Setiap manusia memerlukan harta dan kekayaan untuk memenuhi kebutuhannya. Pasar dalam kaitannya dengan pembangunan ekonomi memang sangat berpengaruh khususnya dalam rangka meningkatkan pendapatan asli daerah yang sangat penting demi kelangsungan pembangunan baik di pusat maupun daerah. Pasar sebagai pusat kegiatan ekonomi yang mendorong dan memperlancar kegiatan bagi masyarakat.

Pasar adalah area tempat jual beli barang dengan jumlah penjualan lebih dari satu baik yang disebut pusat perbelanjaan, pasar tradisional, pertokoan, mall, plasa, pusat perdagangan maupun sebutan lainnya. Pasar tradisional adalah pasar yang dibangun dan dikelola oleh pemerintah, pemerintaah daerah, swasta, badan usaha milik negara dan badan usaha milik daerah termasuk kerjasama dengan swasta dengan tempat usaha berupa toko, kios, los, dan tenda yang dimiliki atau dikelola oleh perdagangan kecil, menengah, swadaya masyarakat atau koperasi dengan usaha skala kecil modal kecil dan dengan proses jual beli barang dengan melalui tawar-menawar. ${ }^{4}$

Sebelum terlalu jauh dan tidak melebar, kajian ini difokuskan pada tinjauan prinsip ekonomi Islam terhadap praktek memasarkan ikan asin. Ikan asin merupakan salah satu komoditi perikanan yang perlu mendapat perhatian, selain harganya yang terjangkau ikan asin juga merupakan kebutuhan jangka panjang bagi masyarakat lokal. Produksi ikan asin dilakukan sendiri oleh penduduk sekitar desa Lambur Luar, karena sebagian besar masyarakat tersebut adalah nelayan.

Ikan asin tersebut tidak hanya dipasarkan kepada para pedagang yang berada di wilayah desa Lambur Luar saja, tetapi juga dikirim ke luar daerah terkadang bahkan ke kota Jambi tetapi bukan skala banyak. Ikan asin bisa menjadi primadona masyarakat luar karena mereka jarang memenuhi bahkan menyantap itu tetapi biasanya hanya dalam skala kecil.

Para nelayan di desa Lambur Luar sendiri terkadang lebih memilih menjual ikannya yang masih basah atau yang masih segar dengan alasan bahwa kalau sudah dikeringkan terjadi penyusutan yang signifikan dan yang membeli juga tidak terlalu banyak karena biasanya konsumen hanya untuk konsumsi sendiri, lain halnya dengan ikan basah yang biasa langsung dikirim dalam skala besar ke kota Jambi.

\section{Mekanisme Praktik Jual Beli Ikan Asin di Desa Lambur}

Dalam kehidupan sehari-hari, ekonomi merupakan sumbu yang dikelilingi kehidupan sosial individu dan masyarakat. Sedangkan tata nilai yang menonjol di zaman sekarang adalah ajaran falsafah yang berbeda dalam mencapai kesejahteraan dan kemakmuran ekonomi. ${ }^{5}$

Islam adalah agama yang multikomplit, multifaktual dan multidimensi dalam memenuhi kehidupan manusia. Ketinggian tata nilai Islam jauh berbeda dengan semua agama. Islam memiliki kekuatan hukum, peraturan, perundang-undangan, tata krama dan tingkah laku. Oleh

\footnotetext{
${ }^{3}$ Ibid., 27.

4 Shobiri, "Jual Beli dalam Pandangan Islam", Jurnal Bisnis dan Manajemen Islam, Volume 3, Nomor 2 (Desember 2015), 10.

${ }^{5}$ Adiwarman A. Karim, Ekonomi Mikro Islami (Jakarta: Rajawali Pers, 2014), 45.
} 
karena itu sangat tidak adil bila petunjuk kehidupan yang lengkap dipisah-pisahkan antara satu bagian dengan bagian lainnya. ${ }^{6}$

Praktik jual beli ikan asin di desa Lambur Luar bahwa penjual dan pembeli adalah orang yang berakal dan yang sudah terbiasa dalam praktik jual beli. Penjual ikan dan pembeli samasama sepakat dan rela ikan itu dibeli oleh pembeli, begitupun sebaliknya. Tidak ada unsur keterpaksaan sama sekali dalam menjual maupun membeli karena setiap manusia tidak bisa menyelesaikan semua urusan tanpa membutuhkan orang lain sebagai timbal balik.

Praktik jual beli ikan asin di desa Lambur Luar pihak penjual maupun pembeli sudah sama-sama dewasa atau baligh sehingga dalam akad jual belinya mereka sudah mampu mengerti dalam jual beli tersebut, artinya antara penjual dan pembeli sudah mengetahui yang mana praktik-praktik yang dilarang oleh Allah atau yang dianjurkan.

Praktik jual beli ikan asin di desa Lambur telah sesuai dengan ketentuan Islam, walaupun masih ada yang mempraktikkan bisnis konvensional. Dalam hal ini penjual maupun pembeli harus dapat mengembangkan penerapan bisnis Islam untuk tujuan kemaslahatan dan tidak mendapat kemadaratan dunia akhirat.

Banyak orang-orang mengharapkan diberlakukannya aturan atau hukum Islam dalam aktifitas ekonomi. Sebaiknya, adapula orang-orang yang bangga bekerja dengan menggunakan sistem ekonomi Barat, seperti sistem kapitalisme dan sosialisme dengan tujuan mau menandingi aturan atau perundang-undangan Islam. Seperti praktik jual beli ikan asin di desa Lambur ditujukan oleh transaksi yang dilakukan antara pedagang dan pembeli didasari atas adanya saling berinteraksi antara keduanya, yaitu melakukan permintaan dan penawaran.

Salah satu yang menjadi hal vital dalam praktik jual beli adalah kerelaan antara dua belah pihak. Sebagian ulama berpendapat bahwa jual beli adalah penukaran harta atas dasar saling rela atau memindahkan hak milik dengan ganti rugi yang dapat dibenarkan. Akan tetapi pergeseran zaman dan perkembangan teknologi membuat hal tersebut dikesampingkan karena adanya kesepahaman tata nilai, seperti halnya yang terjadi praktik jual beli ikan asin di desa Lambur Luar di mana seorang penjual menjual ikan asin yang basah. Dalam hal ini, dapat merugikan pihak konsumen karena dapat membuat ikan tersebut susut atau kurang timbangan yang mana konsumen tersebut membeli untuk dijual kembali. Ada juga terdapat masalah pihak penjual menjual ikan yang rusak sehingga dapat membuat kensumen rugi.

Menyikapi hal di atas, ada beberapa pendapat ulama tentang jual beli tersebut. Kelompok pertama, termasuk di dalamnya adalah al-Bajuri menganggap transaksi ini tidak sah karena menghilangkan salah satu rukun akad, yaitu șighah. Sedangkan pendapat yang didukung oleh Imam Malik dan sebagian ulama Syafi'iyah menganggap bahwa hal terpenting dalam jual beli tidak terdapat pada $\bar{j} j a b$ dan qabul tetapi pada kerelaan antara keduanya (penjual dan pembeli). Dengan demikian, makna yang dijadikan patokan adalah adat kebiasaan masyarakat setempat. Jika satu masyarakat telah menganggapnya sebagai kebiasaan maka hukumnya sah-sah saja. ${ }^{7}$

Praktik jual beli asin di desa Lambur Luar pada dasarnya sah-sah saja, apabila merujuk pada pendapat dari Imam Malik dan pendapat dari sebagaian ulama Syafi'iyah. Karena pola

\footnotetext{
${ }^{6}$ Bukhari Alma dan Donni Juni Priansa, Manajemen Bisnis Syariah: Menanamkan Nilai dan Praktis Syariah dalam Bisnis Kontemporer (Bandung: Alfabeta, t.th), 100.

${ }^{7}$ Suhrawadi K. Lubis, Hukum Ekonomi Islam (Jakarta: Sinar Grafika, 2004), 158.
} 
seperti ini sudah menjadi hal biasa bagi masyarakat. Namun dalam hal jual beli ikan asin di desa Lambur Luar yang dilakukan oleh penjual memiliki berbagai tanggapan dari pembeli. Ada pembeli yang merasa dirugikan, namun ada pula yang menganggapnya sebagai hal yang biasa.

Bagi yang menganggap biasa beralasan karena tujuan mereka bagi konsumen untuk makan dan enak dikonsumsi atau puas. Sehingga yang dilakukan penjual baik itu basah tetapi hanya untuk mengawetkan ikan tidak menjadi permasalahan. Dan ketika pembeli meminta ganti rugi terhadap ikan asin yang dia beli bukan ikan asin yang dimaksud yang diberikan penjual, tetapi ikan lain yang diberikan penjual sehingga penjual mau ganti rugi. Sedangkan yang merasa dirugikan beralasan karena ikannya rusak, tidak sesuai keinginan dan atau ikannya basah.

Praktik jual beli ikan asin di desa Lambur Luar ada yang merasa dirugikan karena ikannya rusak karena pembeli menjual untuk dijual kembali untuk menjual masak, ada juga yang merasa ikannya basah sehingga ikan tersebut timbangannya menjadi berat, ada juga yang merasa ikan yang dibeli tidak sessuai dengan yang dikehendaki. Sehingga adanya ketidakadilan terhadap beberapa pembeli. ${ }^{8}$

Oleh karena itu, sebaiknya pembeli terlebih dahulu menanyakan barang yang ingin dibeli dan memeriksa barang yang ingin dibeli sebelum membayar harga ikan yang ditentukan oleh pembeli, dengan demikian pembeli mengetahui kondisi barang sehingga pembeli tidak merasa dirugikan.

\section{Faktor-Faktor Penghambat Pemasaran Ikan Asin di Desa Lambur Luar}

1. Lingkungan pemasaran

Pemasaran merupakan proses sosial yang dengan proses itu individu dan kelompok mendapatkan apa yang mereka butuhkan dan inginkan dengan menciptakan, menawarkan dan secara bebas mempertukarkan produk dan jasa yang bernilai dengan pihak lain. Proses pemasaran terkait pada lingkungan pemasaran yang dipilih.

Lingkungan pemasaran merupakan lingkungan yang berada di sekitar usaha yang memiliki pengaruh langsung terhadap operasional usaha. Berdasarkan dari hasil pengumpulan data melalui kuisioner dapat diketahui kendala-kendala yang terjadi dalam pemasaran produk olahan ikan laut yang terdapat di UMKM Desa Lambur Luar adalah bahan baku yang sulit didapat karena tergantung keadaan musim, tingkat pendidikan umumnya masih relatif rendah, harga yang tidak stabil di gudang penampung, modal tidak mencukupi untuk mengembangkan usaha pemasaran produk olahan ikan laut, adanya ancaman pendatang baru dan promosi tidak merata.

2. Tingkat pendidikan umumnya masih relatif rendah

Berdasarkaan dari data wawancara sebagian besar pelaku usaha yang tergabung dalam sebuah kelompok UMKM relatif rendah, tingkat pendidikan yang sangat mendominasi adalah tingkat sekolah dasar.

3. Ancaman pendatang baru

Berdasarkan dari hasil pengumpulan data responden mengemukakan bahwa masuknya pendatang baru dalam usaha pengelolahan ikan di desa Lambur dapat

\footnotetext{
${ }^{8}$ Jamal, Wawancara, Muara Sabak Timur, 22 Mei 2020.
} 
meningkatkan intensitas persaingan antar pelaku usaha. Masuknya pendatang baru tergantung pada murah tidaknya hambatan masuk dalam usaha.

4. Promosi tidak merata

Promosi merupakan kegiatan yang bertujuan untuk meningkatkan volume penjualan dengan cara mempengaruhi konsumen baik secara langsung maupun tidak langsung.

\section{Kendala dalam Proses Pemasaran Ikan Asin di Desa Lambur Luar}

1. Bahan baku yang sulit didapat karena tergantung oleh musim

Berdasarkan dari data pengumpulan wawancara, bahwa bahan baku merupakan komponen utama dalam pemasaran. Apabila bahan baku tidak ada maka produk olahan tidak akan ada, begitu juga dengan pemasarannya. Bahan baku sangat dipengaruhi oleh musim. Apabila hujan maka nelayan pemasok tidak akan melaut. Oleh sebab itu, akan muncul permasalahan sulitnya mendapatkan bahan baku produk olahan. ${ }^{9}$

2. Dukungan pemerintah terhadapa produk olahan ikan asin di desa Lambur Luar

Pemerintah Tanjung Jabung Timur berupaya untuk mencapai semaksimal mungkin di dalam meningkatkan produksi, produktivitas, pendapatan nelayan, ekspor komoditi perikanan, pertumbuhan investasi, konsumsi ikan dan dalam mewujudkan kualitas kehidupan terutama di senta-sentra perikanan.

Upaya pemerintah melaksanakan pembangunan pada berbagai titik sektor tidak terkecuali sektor perikanan dan kelautan yang baru dikembangkan. Kemajuan sektor perikanan dan kelautan ini tidak terlepas dari peembinaan, melalui bimbingan, pelatihan dan sosialisasi kepada semua stakeholder terkait.

3. Harga yang tidak stabil

Keberadaan produk yang sejenis di pasaran menyebabkan tidak stabilnya harga produk, akan tetapi kualitas juga sangat menentukan beragamnya harga, apabila produk berkualitas maka harga akan tinggi, begitu juga sebaliknya apabila produk olahan kurang kualitasnya maka harga akan turun. Beberapa responden mengemukakan bahwasannya permasalahan ini terjadi di lapangan khususnya pada produk olahan ikan kering yang diproduksi oleh masyarakat desa Lambur Luar.

4. Modal usaha tidak mencukupi

Berdasarkan hasil wawancara yang ditujukan kepada pelaku usaha pemasaran produk olahan ikan asin, beberapa di antara mereka mengemukakan keluhan akan modal yang tidak cukup untuk mengembangkan usaha produk olahan ikan laut. ${ }^{10}$

Modal merupakan suatu aspek yang sangat dibutuhkan oleh pelaku usaha untuk mengembangkan usahanya, seperti memperluas pasar. Perluasan pasar membutuhkan modal yang cukup untuk mendistribusikan produk olahan. Dengan perluasan pasar maka pelaku usaha juga melakukan produksi yang besar atau bertambah dari produksi sebelumnya. Oleh sebab itu, modal sangat dibutuhkan oleh pelaku usaha produk olahan ikan laut. Ada beberapa hal yang harus diperhatikan dalam distribusi ikan yang baik. Pertama, distribusi hasil perikanan yang menggunakan sarana transportasi harus bersih

\footnotetext{
${ }^{9}$ Siti, Wawancara, Muara Sabak Timur, 22 Mei 2020.

${ }^{10}$ Amir, Wawancara, Muara Sabak Timur, 22 Mei 2020.
} 
dan mampu menghindari kontaminasi; didesain sedemikian rupa sehingga tidak merusak produk di mana permukannya harus rata, mudah dibersihkan, dan disanitasi; apabila menggunakan es sebagai pendingin, harus dilengkapi saluran pembuangan untuk menjamin lelehan es tidak menggenangi produk; dilengkapi peralataan untuk menjaga suhu tetap terjaga selama pengangkutan; dan mampu melindungi produk dari resiko penurunan mutu.

Kedua, sarana berupa kendaraan pengangkutan tidak digunakan untuk tujuan lain secara bersamaan untuk menghindari terjadinya kontaminasi terhadap produk hasil perikanan. Ketiga, apabila kendaraan pengangkutan digunakan untuk mengangkut produk lain secara bersamaan, harus dipisahkan dan dijamin kebersihannya agar tidak mengkontaminasi produk hasil perikanan. Keempat, pengangkutan hasil perikanan tidak boleh dicampur dengan produk lain yang dapat mengakibatkan kontaminasi atau mempengaruhi higienitas, kecuali produk tersebut dikemas sedemikian rupa sehingga mampu melindungi produk tersebut. Kelima, pengangkutan hasil perikanan dalam keadaan hidup harus mampu mempertahankan hasil perikanan tersebut tetap terjaga kondisi dan mutunya.

Cara distribusi produk hasil perikanan sangat dipengaruhi oleh beberapa hal, diantaranya jenis produk, jenis alat angkut, dan kondisi penyimpanan. Proses distribusi untuk produk kering berbeda dengan produk basah. Begitupun dengan jenis alat angkut yang digunakan, bila produk yang didistribusikan berupa produk basah, maka sarana transportasi yang digunakan harus dilengkapi dengan alat pendingin. Jenis produk yang didistribusikan juga akan berpengaruh terhadap kondisi penyimpanan, sehingga kondisi penyimpanan harus disesuaikan dengan jenis produk yang akan didistribusikan.

\section{Tinjauan Prinsip Ekonomi Islam Terhadap Praktik Jual Beli Ikan Asin di Desa Lambur Luar}

Agama Islam pada esensinya merupakan panduan atau bimbingan moral (nilai-nilai ideal) bagi perilaku manusia. Panduan moral tersebut pada garis besarnya bertumpu pada ajaran akidah, aturan hukum (syariah) dan budi pekerti luhur. Tampaklah bahwa antara agama Islam dan ekonomi terdapat ketersinggungan objek. Dalam kaitan antara keduanya, Islam berperan sebagai panduan moral terhadap fungsi produksi, distribusi dan konsumsi. Islam memandang kehidupan sebagai satu kesatuan yang tidak dapat dipilah-pilah serta memandang kehidupan seseorang sebagai bagian yang tidak terpisahkan dari kehidupan masyarakat masing-masing individu saling melengkapi dalam tatanan sosial. Allah menciptakan manusia sebagai makhluk sosial yang saling membutuhkan bantuan kepada sesamanya untuk saling tukar menukar guna memenuhi kebutuhan hidupnya.

Jual beli merupakan interaksi yang paling sering dilakukan kebanyakan orang dalam kehidupan sehari-hari. Baik itu di pasar, toko, warung, ataupun kios. Dalam fikih muamalah, ada beberapa prinsip dasar dalam bermuamalah, yaitu adanya mubah (kebolehan), 'an taradin (kerelaan), mendatangkan maslahat dan memelihara nilai keadilan. Semua prinsip tersebut harus menjadi dasar dan pedoman dalam bermuamalah khususnya jual beli agar tidak ada yang pihak yang dirugikan, seperti dalam firman Allah: 


$$
\text { يا أيها الذين آمنوا لا تأكلوا أموالكم بينكم بالباطل إلا أن تكون تحارة عن تراض منكم' }
$$

"Hai orang-orang beriman, janganlah kamu saling memakan harta sesamamu dengan jalan yang batil, kecuali dengan jalan perniagaan yang berlaku dengan suka sama-suka diantara kamu."12

Tujuan dari jual beli pada dasarnya adalah mencari keuntungan, maka keuntungan merupakan tujuannya yang paling mendasar, bahkan tujuan asli dari perniagaan. Asal dari keuntungan adalah disyaratkan, kecuali jika diambil dari cara yang haram maka hasilnya juga haram, sebagaimana firman Allah:

$$
\begin{aligned}
& \text { الذين يأكلون الربا لا يقومون إلا كما يقوم الذي يتخبطه الشيطان من المس ذلك بأفم قالوا إنما البيع مثل الربا } \\
& \text { وأحل الله البيع وحرم الربا فمن جاءه موعظة من ربه فانتهى فله ما سلف وأمره إلى الله ومن عاد فأولئك أصحاب } \\
& \text { النار هم فيها خالدون }
\end{aligned}
$$

"Orang-orang yang makan (mengambil) riba tidak dapat berdiri melainkan seperti berdirinya orang yang kemasukan syaitan lantaran (tekanan) penyakit gila. Keadaan mereka yang demikian itu adalah disebabkan mereka berkata sesungguhnya jual beli itu sama dengan riba, padahal Allah telah menghalalkan jual beli dan mengharmkan riba. Orang-orang yang telah sampai kepadanya larangan dari Tuhannya, lalu terus berhenti (dari mengambil riba), maka baginya apa yang telah diambilnya dahulu (sebelum datang larangan), dan urusannya (terserah) kepada Allah. Orang yang kembali (mengambil riba), maka orang itu adalah penghuni-penghuni neraka, mereka kekal di dalamnya". ${ }^{14}$

Kegiatan jual beli islami harus berada di bawah prinsip bermuamalah, yaitu di antaranya keadilan, sehingga kegiatan yang melanggar keadilan dan mendatangkan kezaliman dilarang oleh Islam, seperti monopoli, menimbun barang, eksploitasi dan perdagangan tidak sah lainnya. Sebagaimana firman Allah dalam al-Quran yang memerintahkan agar manusia berlaku adil.

\section{Cara Distribusi Ikan yang Baik}

Pada dasarnya, distribusi produk hasil perikanan dapat dilakukan dengan model penerapan sistem rantai dingin. Dalam sistem ini, suhu ikan hasil tangkapan atau hasil panen diupayakan selalu tetap rendah agar terjaga kesegarannya, yaitu dengan mengoptimalkan penggunaan es dalam penyimpanannya.

Sistem rantai dingin yang diterapkan dalam distribusi dan transportasi ikan dipersyaratkan bahwa semua kendaraan yang digunakan untuk mempertahankan suhu dingin yang dibutuhkan baik untuk ikan segar maupun mengawetkan produk beku. Akan lebih baik

\footnotetext{
11 al-Quran, 4: 29.

12 Depertemen Agama RI, Al-Quran dan Terjemahnya (Jakarta: Proyek Pengadaan Kitab al-Qur'an, 1984$), 112$.

13 al-Quran, 2: 275.

${ }^{14}$ Depertemen Agama RI, Al-Quran dan Terjemahnya, 47.
} 
dengan menggunakan pintu dalam yang dapat menutup sendiri dengan fleksibel untuk mengurangi kehilangan udara dingin waktu pintu kendaraan pengangkut dibuka.

Pada pengangkutan jarak jauh sebaiknya suhu dipertahankan $-18 \mathrm{C}^{\mathrm{o}}$ atau lebih rendah dan ini bisa dicapai dengan pendinginan mekanis, pemakaian es kering, sirkulasi gas cair yang dingin. Untuk refrigerasi dan ketelitian dalam pemuatan, operasi dan pemeliharaannya, sewaktu-waktu harus diperiksa dengan mengukur suhu produk pada awal dan akhir perjalanan. Pengangkutan harus dilakukan dengan hati-hati agar produk perikanan tidak terkena suhu tinggi selama pemuatan dan pembongkaran kendaraan pengangkut.

\section{Resiko-resiko yang Dihadapi oleh Pedagang Ikan Kering}

Dalam setiap usaha dagang pasti akan mengalami yang namanya risiko. Risiko merupakan bagian yang tidak terpisahkan dari kehidupan karena segala aktivitas pasti mengandung risiko bahkan ada anggapan yang mengatakan tidak ada hidup tanpa risiko sebagaimana tidak ada hidup tanpa kematian. Risiko merupakan kemungkinan terjadi suatu kerugian yang tidak diduga atau tidak diinginkan, jadi ketidakpastian atau kemungkinan terjadinya sesuatu yang apabila terjadi mengakibatkan kerugian. ${ }^{15}$

Menurut Amir, risiko-risiko yang dihadapi saat berdagang ikan kering ini adalah sepi pembelinya, dan persaingan harga. ${ }^{16}$ Sedangkan menurut Aminah yaitu sepi pembeli, maksudnya adalah apabila dagangan ibu ini sepi maka akan berpengaruh pada pendapatan pedagang ikan kering ini. Risiko lain adalah adanya persaingan harga mengakibatkan harga penjualan pedagang tidak merata. ${ }^{17}$

Sedangkan menurut Jamal dan Siti, yang menyebabkan ikan kering rusak adalah cuaca buruk atau tidak mendukung cuacanya, kadang hujan kadang tidak sehingga ikan harus disimpan lama yang mengakibatkan ikan menjadi busuk dan rusak. Ketika dijual pun harus dipisahkan, yang bagus dijual dengan harga modal awal sedangkan yang rusak dijual dengan harga yang murah. ${ }^{18}$

Faktor lain menurut Hajar adalah konsumen yang malas berbelanja karena jarak pasar dengan rumah mereka cukup jauh, juga susahnya kendaraan untuk ke pasar dan cuaca yang tidak menentu. ${ }^{19}$ Lain halnya dengan Kamsina yang menyatakan bahwa terjadinya persaingan harga ikan kering disebabkan barang yang diinginkan oleh konsumen sangat terbatas yang diakibatkan cuaca buruk sehingga para nelayan tidak melaut sehingga pedagang susah mendapatkan ikan. ${ }^{20}$

\section{Kesimpulan}

Praktik jual beli ikan asin di desa Lambur Luar di mana seorang penjual menjual ikan asin yang masih basah serta terdapat ikan yang rusak juga tidak sesuai dengan kata-kata awal. Ada yang menganggapnya sebagai hal yang biasa namun ada juga yang merasa dirugikan.

\footnotetext{
15 Seosini Djojosoedarso, Prinsip-Prinsip manajemen dan Risiko Asuransi, cet. 1 (Jakarta: Salemba Empat, 1999), 2.

${ }^{16}$ Amir, Wawancara, Muara Sabak Timur, 22 Mei 2020.

17 Aminah, Wawancara, Muara Sabak Timur, 22 Mei 2020.

${ }^{18}$ Jamal dan Siti, Wawancara, Muara Sabak Timur, 22 Mei 2020.

${ }^{19}$ Hajar, Wawancara, Muara Sabak Timur, 22 Mei 2020.

${ }^{20}$ Kamsina, Wawancara, Muara Sabak Timur, 22 Mei 2020.
} 
Bagi yang menganggap biasa beralasan karena tujuan mereka bagi pembeli untuk makan dan enak dikonsumsi atau puas. Sehingga yang dilakukan penjual baik itu basah tetapi hanya untuk mengawetkan ikan tidak menjadi permasalahan. Namun ada juga yang merasa dirugikan karena ikannya rusak dikarenakan pembeli menjual untuk dijual kembali, ada juga yang merasa ikannya basah sehingga ikan tersebut timbangannya menjadi berat, ada juga yang merasa ikan yang dibeli tidak sesuai dengan yang dikehendaki. Sehingga adanya ketidakadilan terhadap beberapa pembeli.

Pandangan hukum Islam terhadap praktik jual beli ikan asin di desa Lambur Luar terdapat dua kesimpulan hukum, yaitu pertama, hukumnya mubah karena pembeli dan penjual di hati mereka ada kerelaan. Kedua, hukumnya haram karena tidak ada kerelaan dari pembeli ikan asin tersebut.

\section{Daftar Rujukan}

Al Arif, M. Nur Rianto. Pengantar Ekonomi Syariah Teori dan Praktik. Bandung: CV Pustaka Setia, 2015.

ash-Shiddieqy, M. Hasbi. Tafsir Al-Qur'anul Majid An-Nurr. Semarang: Pustaka Rizki, 2000. Alim, Muhammad. Etika dan Perlindungan dalam Ekonomi Islam. Yogyakarta: BPFE, 2004.

Alma, Bukhari dan Donni Juni Priansa. Manajemen Bisnis Syariah: Menanamkan Nilai dan Praktis Syariah dalam Bisnis Kontemporer. Bandung: Alfabeta, t.th.

Depertemen Agama RI. Al-Quran dan Terjemahnya. Jakarta: Proyek Pengadaan Kitab alQur'an, 1984.

Djojosoedarso, Seosini. Prinsip-Prinsip Manajemen dan Risiko Asuransi, cet. 1. Jakarta: Salemba Empat, 1999.

Haroen, Nasrun. Fiqh Muamalah Kontemporer. Jakarta: Rajawali Pers, 2016.

Juniarsih. "Analisis Penerapan Etika Bisnis Islam Pada Industri Ikan Teri (Studi Pada Industri Ikan Teri di Pulau Pasaran Kota Bandar Lampung)", Skripsi--Universitas Islam Negeri Raden Intan Lampung, 2018.

Karim, Adiwarman A. Ekonomi Mikro Islam. Jakarta: Rajawali Pers, 2014.

Lestari, Widya. "Etika Bisnis Pedagang Ikan Asin Ditinjau Dari Ekonomi Islam (Studi Di Kelurahan Sumber Jaya Pulau Baai Kota Bengkulu)", Skripsi--Institut Agama Islam Negeri Bengkulu, 2016.

Lubis, Suhrawadi K. Hukum Ekonomi Islam. Jakarta: Sinar Grafika, 2004.

Maleong, Lexy. Metode Penelitian Kualitatif. Bandung: Remaja Rosdakarya, 2013.

Ratna, Nyoman Kutha. Metodologi Penelitian: Kajian Budaya dan Ilmu Sosial Humaniora Pada Umumnya. Yogyakarta: Pustaka Pelajar, 2010.

Shobiri. "Jual Beli dalam Pandangan Islam”, Jurnal Bisnis dan Manajemen Islam, Volume 3, Nomor 2 (Desember 2015).

Sugiyono. Metode Penelitian Kuantitatif Kualitatif dan R\&D. Bandung: Alfabeta, 2013.

Sukmadinata, Nana Syaodih. Metode Penelitian Pendidikan. Bandung: PT Aja Rosdakarya Offset, 2009.

Ulyati, Nur Faeni. "Strategi Pemasaran Pedagang Pasar Tradisional dalam Perspektif Ekonomi Islam (Studi Kasus di Pasar Lebaksiu-Tegal)", Skripsi--Universitas Islam Negeri Walisongo Semarang, 2015. 